\title{
Pelayanan Penumpang Angkutan Umum Kota Trayek Sudiang - Sentral Kota Makassar
}

\author{
Ismawati Tandirerung ${ }^{* 1}$, Jumeitri Ramba ${ }^{* 2}$, Rais Rachman ${ }^{* 3}$, H. Nur Ali ${ }^{* 4}$ \\ *1,2 Mahasiswa Prodi Teknik Sipil, Universitas Kristen Indonesia Paulus, Makassar, Indonesia \\ ismawatitandirerung1@gmail.com, jumeitriramba1@gmail.com \\ *3,4 Dosen Prodi Teknik Sipil, Universitas Kristen Indonesia Paulus, Makassar, Indonesia \\ Rais.Rachman@gmail.com , nurali.mt,@gmail.com
}

\begin{abstract}
ABSTRAK
Angkutan umum perkotaan sebagai salah satu bagian dari transportasi merupakan salah satu kebutuhan pokok masyarakat kota dan merupakan bagian yang tidak dapat dipisahkan dengan kehidupan kota pada umumnya.Penelitian ini bertujuan untuk menganalisis kinerja pelayanan penumpang angkutan umum kota (mikrolet) pada trayek Sudiang - Sentral Makassar. Pengguna jasa angkutan umum kota (mikrolet) lebih dominan perempuan dimana rentang umurnya 20-29 tahun dan pendidikan terakhir yaitu SLTA dengan jenis pekerjaannya yaitu wiraswasta yang berpenghasilan di atas lima juta. Moda yang digunakan yaitu angkutan kota dengan jarak tempuh sejauh 10-15 km dan waktu tempuh 21-30 menit dimana rantai perjalanannya dari rumah ke kantor dengan biaya $\mathrm{Rp}$ 250.000-Rp 400.0000. Rata-rata responden tidak puas terhadap kinerja angkutan umum kota (mikrolet) hal ini dapat dilihat dari kecepatan waktu, kemampuan menghindari kemacetan dan daya jelajah yang masih rendah.
\end{abstract}

Kata Kunci : angkutan umum, kepuasan penumpang, tingkat pelayanan kinerja

\begin{abstract}
Urban public transportation as one part of transportation is one of the basic needs of urban society and is an inseparable part of city life in general. This study aims to analyze the performance of the public public transport service passengers (mikrolet) on the Sudiang - Central Makassar route. Users of city public transport services (microbuses) are more dominant in women where the age range is $20-29$ years and the last education is high school with the type of work that is self-employed who earn more than five million. Modes used are public transportation with a distance of 10-15 km and a travel time of 21-30 minutes where the chain of travel from home to office at a cost of $\mathrm{Rp} 250,000-\mathrm{Rp} 400,0000$. On average respondents are not satisfied with the performance of city public transportation (microbus) seen from the speed of time, the ability to avoid congestion and cruising is still low.
\end{abstract}

Keywords: : public transportation, passenger satisfaction, service level performance

\section{PENDAHULUAN}

Kualitas pelayanan merupakan suatu kondisi atau karakteristik dari angkutan umum yang diharapkan oleh pengguna yang terdiri dari elemen-elemen, seperti: Keselamatan, meliputi keselamatan pada waktu menggunakan angkutan umum (in-vehicles) dan pada waktu kendaraan berhenti (at-stops); Kenyamanan, meliputi kenyamanan fisik penumpang, keindahan dan lingkungan. Kenyamanan fisik penumpang meliputi kenyamanan dalam kendaraan maupun di tempat perhentian, misalnya kenyamanan tempat duduk dan tempat berdiri, kemudahan pada waktu masuk dan keluar kendaraan, tempat meletakan barang dan lain-lain. Keindahan meliputi tempat duduk yang bersih, tempat perhentian yang menarik, sedangkan kenyamanan meliputi perlindungan lingkungan terhadap polusi udara dan suara; Kemudahan pencapaian meliputi distribusi rute yang menjangkau seluruh wilayah, kapasitas kendaraan, frekuensi pelayanan dan pengoperasian jadwal, identifikasi tempat perhentian dan distribusi papan informasi [1]; Keandalan, elemen ini tergantung dari penyediaan pelayanan khusus yang diberikan oleh operator, misalnya adanya informasi apabila terjadi perubahan jadwal keberangkatan/kedatangan kendaraan, jaminan kemudahan pergantian kendaraan dan lain-lain; perbandingan biaya, ini meliputi jaminan ongkos/biaya, jarak tempuh minimum, kemudahan pergantian moda, pengurangan ongkos perjalanan untuk kelompok khusus (anak-anak, pelajar dan lainlain) serta karcis berlangganan; efisiensi, yang meliputi tingginya kecepatan rata-rata, waktu tunggu minimum, jarak perjalanan yang dekat dengan tempat perhentian kendaraan umum, koordinasi dan 
pergantian jadwal dengan meminimumkan ketidaknyamanan penumpang, pelayanan cepat dan khusus.

Tujuan dari penelitian ini adalah untuk mengetahui karakteristik penumpang yang menggunakan angkutan umum perkotaan pada trayek Sudiang Sentral Makassar dan mengetahui kinerja pelayanan angkutan umum perkotaan (mikrolet) pada trayek Sudiang - Sentral Makassar (trayek D).

\section{Jenis Penelitian}

Penelitian ini merupakan penelitian survei yang bertipe deskriptif. Tipe penelitian deskriptif karena pada penelitian ini akan menggambarkan kinerja pelayanan angkutan umum perkotaan (mikrolet) trayek Sudiang-Sentral Makassar.

\section{Sumber Data}

Sumber data pada penelitian ini adalah sumber data primer yaitu data yang langsung berasal dariresponden yaitu para penumpang angkutan umum perkotaan(mikrolet) trayek Sudiang-Sentral Makassar.

\section{Cara Penyajian Data}

Dalam penulisan ini data disajikan dalam bentuk tabel dan grafik kemudian dijelaskan dalam bentuk tulisan.

\section{Lokasi dan Waktu Penelitian}

Lokasi dan objek penelitian dilakukan di dalam angkutan umum pada trayek D (Makassar MallTerminal Regional Daya-Perumnas Sudiang). Objek penelitian yang ditinjau adalah angkutan umum jenis mikrolet (pete-pete) dimana panjang trayek $D$ adalah 23,3 km. Penelitian ini dilakukan selama sepuluh hari untuk mendapatkan perbandingan data. Penelitian dilkukan pada jam sibuk pagi 06.00-08.00, 11.0013.00, dan pada sore hari pada pukul 16.00-18.00 wita.

\section{Penetapan Jumlah Sampel}

Sampel merupakan sebagian dari populasi. Dalam menentukan jumlah sampel yang akan diteliti digunakan rumus Slovin, sampel yang digunakan sebanyak 93 unit kendaraan.

\section{Teknik Analisis Data}

a. Kompilasi Data

Kompilasi data adalah suatu proses pengumpulan data untuk diseleksi, ditabulasi dan dikelompokkan secara sistematis sesuai dengan kebutuhan data yang diperlukan. Data sebaran (kuesioner) yang berisi tentang karakteristik penumpang dan persepsi penumpang untuk mengetahui kinerja angkutan umum kota (mikrolet).

\section{b. Tabulasi Data}

Data yang telah dikelompokan kemudian ditabulasi menggunakan program SPSS. Tabulasi data dilakukan dengan pembuatan tabel pada program SPSS yang berisikan data yang akan dioleh yang sudah diberi kode tertentu sesuai dengan analisis yang dibutuhkan.

\section{Penelitian Terdahulu}

Study on the travel behavior of worker living in the Makassar suburban memberikan hasil bahwa pekerja lebih memperhatikan pengaruh waktu kedatangan dan waktu perjalanan dibandingkan dengan biaya perjalanan [2].

Pelayanan transportasi umum bus damri khusus wanita di Kota Surabaya dengan hasil tingkat keamanan dan kenyamanan halte dirasa kurang baik, keterjangkauan dirasa cukup baik, fasilitas penyandang cacat kurang memadai, dan jadwal yang kurang jelas [3].

Penelitian mengenai analisis kualitas pelayanan jasa penumpang angkutan laut di unit pelaksana teknis pos batas laut Liem Hie Djung Kabupaten Nunukan dengan hasil terdapat beberapa fasilitas fisik yang rusak dan kurangnya jumlah petugas [4].

Analisis kualitas pelayanan angkutan umum di Kota Yogyakarta dengan hasil responden tidak puas terhadap kualitas pelayanan angkutan umum [5].

Analisis kepuasan atas kualitas pelayanan angkutan umum bus damri di Kota Bandung (Trayek Leuwipanjang - Dipati Ukur Non AC) menghasilkan tingkat kepuasan penumpang 0,77 dalam arti penumpang tidak puas dengan pelayanan bus damri [6].

Analisis pelayanan transportasi angkutan kota di Kota Ternate menghasilkan rute angkutan kota beberapa di daerah perbukitan masih kurang [7].

\section{HASIL DAN PEMBAHASAN}

\section{Karakteristik Responden \\ a. Jenis Kelamin}

Berdasarkan data di atas diketahui bahwa pengguna angkutan kota (mikrolet) didominasi oleh perempuan. Dimana pada pagi hari sebanyak $86 \%$ dari jumlah penumpang pada siang hari $87 \%$ dari jumlah penumpang dan pada sore hari sebanyak $75,6 \%$ dari jumlah penumpang sedang laki-laki pada pagi hari sebanyak $13.6 \%$ dari jumlah penumpang, siang hari $12.5 \%$ dari jumlah responden dan pada sore hari sebanyak $24.4 \%$ dari jumlah penumpang. 
Karakterristik responden berdasarkan jenis kelamin dapat dilihat pada Gambar 1.

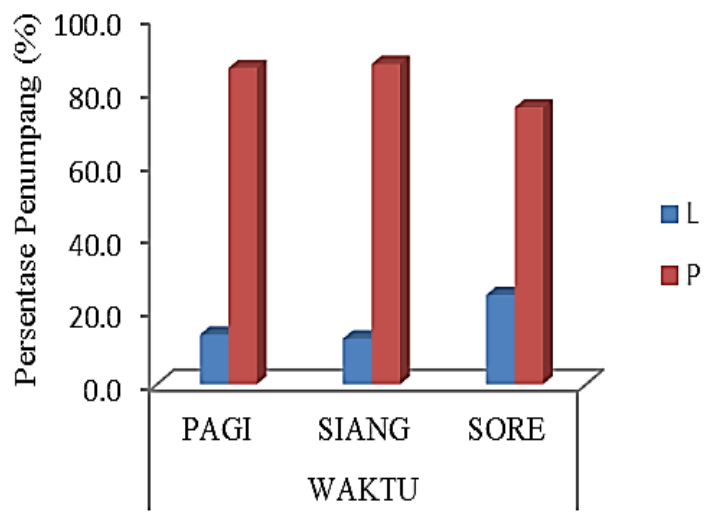

Gambar 1. Karakteristik responden berdasarkan jenis kelamin

\section{b. Pekerjaan}

Pengguna angkutan umum yang dominan pada pagi hari adalah pekerja swasta yaitu sebanyak $27.5 \%$ dari jumlah penumpang, dan pada siang hari didominasi oleh lainnya (ibu rumah tangga) yaitu sebanyak $34.4 \%$ dari jumlah penumpang, sedang pada sore hari didominasi oleh pekerja wiraswasta sebanyak $37.1 \%$ dari jumlah penumpang. Karakteristik responden berdasarkan jenis pekerjaan dapat dilihat pada Gambar 2.

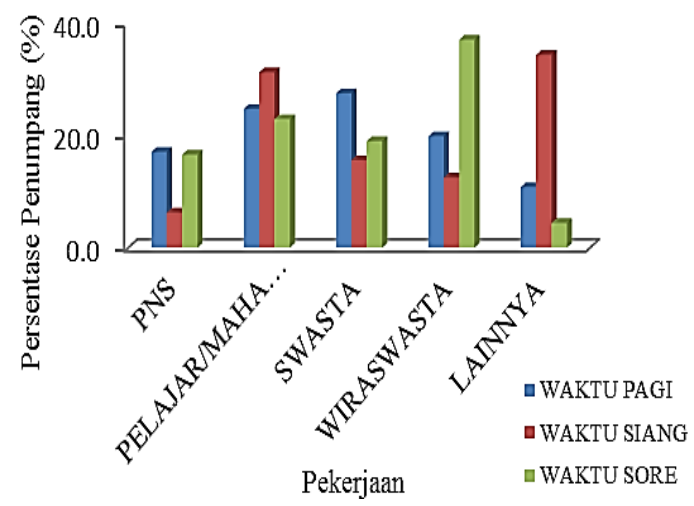

Gambar 2. Karakteristik responden berdasarkan jenis pekerjaan

\section{c. Umur}

Dari hasil penelitian dapat dilihat bahwa pengguna jasa angkutan kota (mikrolet) berdasarkan umur di atas 50 tahun pada pagi hari yaitu sebanyak $2.8 \%$ dari jumlah penumpang, untuk siang hari yaitu sebanyak $12.5 \%$ dari jumlah penumpang, untuk sore hari $1.5 \%$ dari jumlah penumpang, untuk umur $40-50$ pada pagi hari yaitu sebanyak $10.5 \%$ dari jumlah penumpang, untuk siang hari yaitu sebanyak 6,3\% dari jumlah penumpang, dan untuk sore hari yaitu sebanyak $4.9 \%$ dari jumlah penumpang. Untuk umur 30-39 pada pagi hari yaitu sebanyak $23.3 \%$ dari jumlah penumpang, untuk siang hari yaitu sebanyak $12.5 \%$ dari jumlah penumpang, dan pada sore hari yaitu sebanyak $20.5 \%$ dari jumlah penumpang. Untuk umur 20-29 pada pagi hari yaitu sebesar $50.9 \%$ dari jumlah penumpang, untuk siang hari yaitu sebanyak $43.8 \%$ dari jumlah penumpang, dan pada sore hari yaitu $59.5 \%$ dari jumlah penumpang. Untuk umur di bawah 20 pada pagi hari yaitu sebanyak $12.5 \%$ dari jumlah penumpang, untuk siang hari sebanyak $25 \%$ dari jumlah penumpang, dan pada sore hari yaitu sebanyak $13,7 \%$ dari jumlah penumpang. Karakteristik responden berdasarkan kelompok umur dapat dilihat pada Gambar 3.

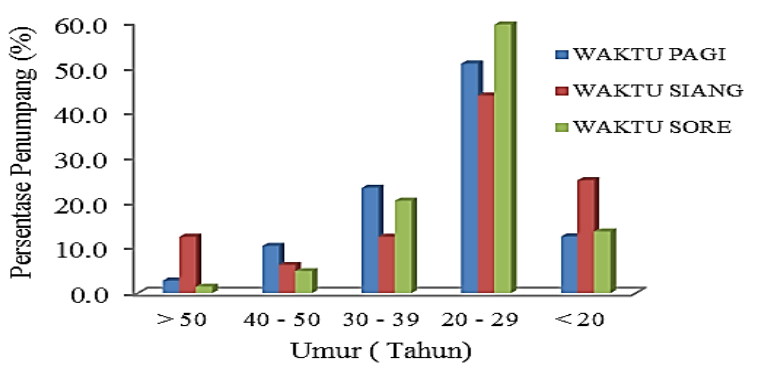

Gambar 3. Karakteristik reponden berdasarkan umur

\section{d. Tingkat Pendidikan Terakhir}

Berdasarkan penelitian di atas dapat dilihat tingkat pendidikan terakhir yang dominan pada pagi adalah S1 sebanyak $40.8 \%$ dari jumlah penumpang, pada siang hari tingkat pendidikan yang dikategorikan dalam lainnya (SMP ataupun yang tidak dalam konteks bersekolah) yaitu sebanyak $43.8 \%$ dari jumlah penumpang, sedang pada sore hari didominasi oleh SLTA sebanyak $43.9 \%$ dari jumlah penumpang. Karakteristik responden berdasarkan tingkat pendidikan terakhir disajikan pada Gambar 4.

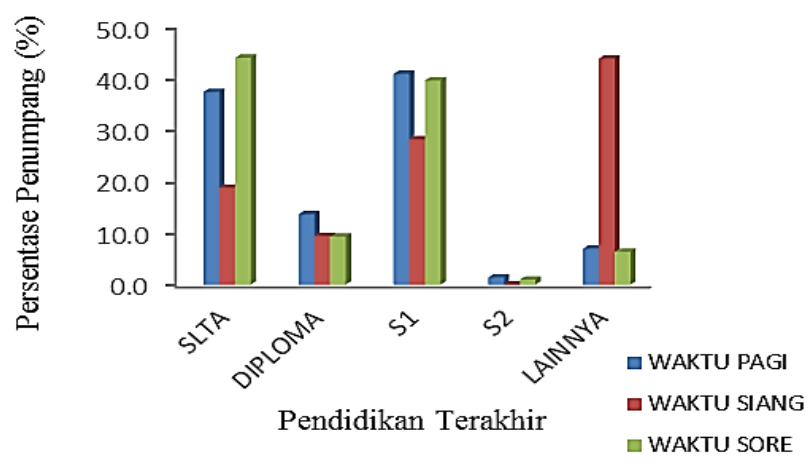

Gambar 4. Karakteristik responden berdasarkan tingkat pterakhir

\section{e. Penghasilan Per Bulan}

Dari penelitian dapat diketahui responden yang berpenghasilan tidak tetap/ tidak berpenghasilan 
sebanyak $38 \%$, responden yang berpenghasilan kurang dari dua juta sebanyak $8,7 \%$, responden yang berpenghasilan 2-3 juta sebanyak 16,3\%, responden yang berpenghasilan sebanyak 3-4 juta. sebanyak $24 \%$, responden yang berpenghasilan lebih dari 5 juta sebanyak 1,8\%. Karakteristik responden berdasarkan penghasilan per bulan disajikan pada Gambar 5.

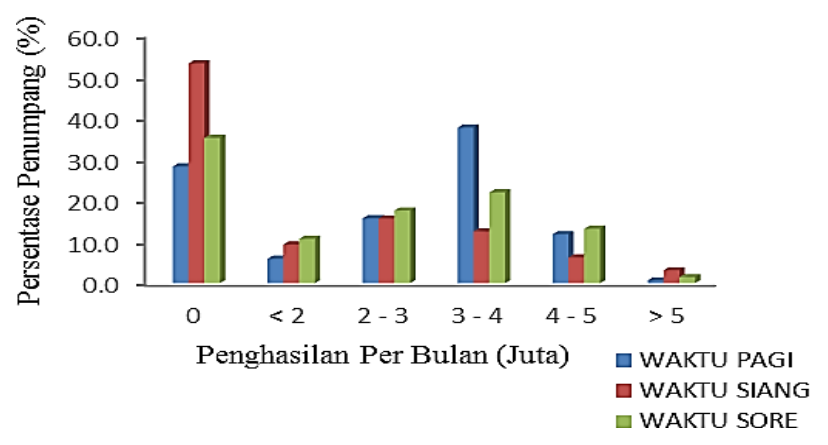

Gambar 5. Karakteristik responden berdasarkan penghasilan

\section{f. Jarak Tempuh}

Dari penelitian dapat diketahui persentase penumpang terbesar berdasarkan jarak tempuh yaitu pada pagi hari untuk $10-14 \mathrm{~km}$ sebesar $39.7 \%, 5$ $9 \mathrm{~km}$ sebesar $30.3 \%, 15-19 \mathrm{~km}$ sebesar $22.6 \%$, $20-24 \mathrm{~km}$ sebesar $7 \%$, dan $25-30 \mathrm{~km}$ sebesar $0.3 \%$, pada siang hari untuk $10-14 \mathrm{~km}$ sebesar $37.5 \%, 5-9 \mathrm{~km}$ sebesar $37.5 \%, 15-19 \mathrm{~km}$ sebesar $12,5 \%$, dan $20-24 \mathrm{~km}$ sebesar $12.5 \%$, pada sore hari untuk $10-14 \mathrm{~km}$ sebesar $42.9 \%, 5$ $9 \mathrm{~km}$ sebesar $30.2 \%, 15-19 \mathrm{~km}$ sebesar $24.4 \%$, $20-24 \mathrm{~km}$ sebesar $2.0 \%$, dan $25-30 \mathrm{~km}$ sebesar $0.5 \%$. Karakteristik responden berdasarkan jarak tempuh perjalanan dapat dilihat pada Gambar 6 .

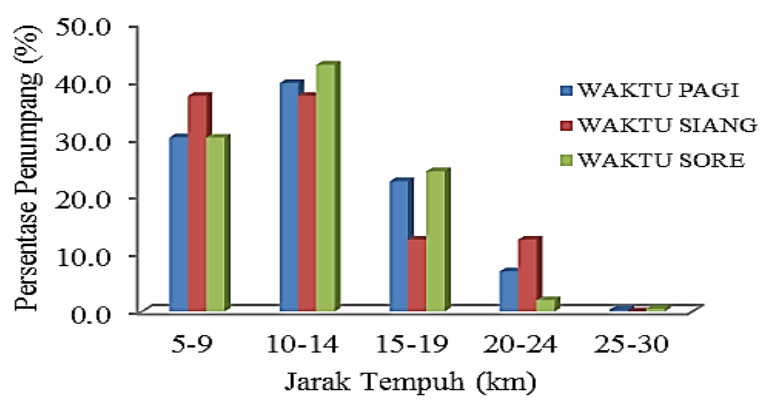

Gambar 6. Karakteristik berdasarkan jarak tempuh

\section{g. Waktu Tempuh Normal}

Dari penelitian dapat diketahui presentase penumpang terbesar berdasarkan waktu tempuh normal yaitu pada pagi hari untuk 21 - 30 menit sebesar $32.4 \%$ dari jumlah penumpang, untuk 31 40 menit sebesar $30.7 \%$ dari jumlah penumpang, untuk 10 - 20 menit sebesar $22.0 \%$ dari jumlah penumpang, untuk 41 - 50 menit sebesar $10.8 \%$, untuk $51-60$ menit sebesar $3.1 \%$, untuk $71-80$ menit sebesar $0,7 \%$, dan untuk pukul $61-70$ menit sebesar $0,3 \%$, pada siang hari untuk $10-20$ menit sebesar $31,3 \%$, untuk 31 - 40 menit sebesar $28,1 \%$, untuk $21-30$ menit sebesar $18.8 \%$, untuk $41-50$ menit sebesar $9.4 \%$, untuk $51-60$ menit sebesar $6.3 \%$, dan untuk $71-80$ menit sebesar $6.3 \%$, pada sore hari untuk $21-30$ menit sebesar $37,6 \%$, untuk 10 - 20 menit sebesar $25,9 \%$ untuk 31 - 40 menit sebesar $16.6 \%$, , untuk $41-50$ menit sebesar 10.7 $\%$, untuk $51-60$ menit sebesar $7.8 \%$, dan untuk 71 - 80 menit sebesar $1.5 \%$. Karakteristik responden berdasarkan lama waktu perjalanan dapat dilihat pada Gambar 7.

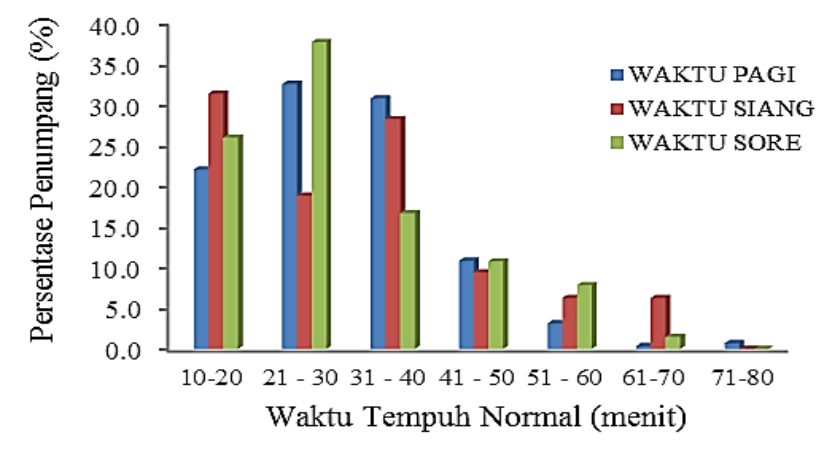

Gambar 7. Karakteristik responden berdasarkan lama waktu tempuh perjalanan

\section{h. Rantai Perjalanan}

Berdasarkan penelitian dapat diketahui bahwa rantai perjalanan pengguna angkutan umum pada pagi hari yaitu dari rumah-kantor sebanyak $73, . \%$ dari jumlah penumpang, pengguna angkutan umum dari rumahantar-kantor pada siang hari sebanyak $3.1 \%$ dari jumlah penumpang, pengguna angkutan dari rumahlain-lain-kantor pada siang hari sebanyak $9.4 \%$ dari jumlah penumpang, sedangkan pengguna angkutan umum dari rumah-lain-lain pada sore hari sebanyak $31.2 \%$ dari jumlah penumpang. Karakteristik responden berdasarkan rantai perjalanan dapat dilihat pada Gambar 8.

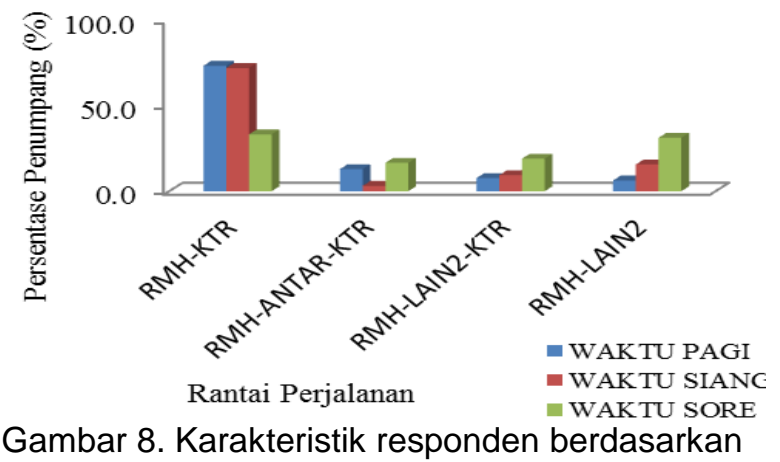
rantai perjalanan

i. Biaya Perjalanan Menggunakan Angkutan Kota 
Dari hasil penelitian dapat diketahui bahwa biaya perjalanan menggunakan angkutan umum pada pagi hari untuk biaya Rp.250.000-400.000 yaitu sebanyak $82,2 \%$ dari jumlah penumpang, pada siang hari sebanyak $90.6 \%$ dari jumlah penumpang sedangkan pada sore hari sebanyak $74.6 \%$ dari jumlah penumpang. Untuk biaya perjalanan sebesar Rp.401.000-550.000 pada pagi hari yaitu sebanyak $15 \%$ dari jumlah penumpang, pada siang hari sebanyak $9.4 \%$ dari jumlah penumpang dan pada sore hari sebanyak $24.9 \%$ dari jumlah penumpang. Untuk biaya perjalanan sebesar Rp.551.000-700.000 pada pagi hari yaitu sebanyak $2.4 \%$ jumlah penumpang, dan pada sore hari sebanyak 5\% dari jumlah penumpang. Untuk yang lebih dari Rp.700.000 pada pagi hari yaitu sebanyak 3\% dari jumlah penumpang, Karakteristik responden berdasarkan biaya perjalanan dapat dilihat pada

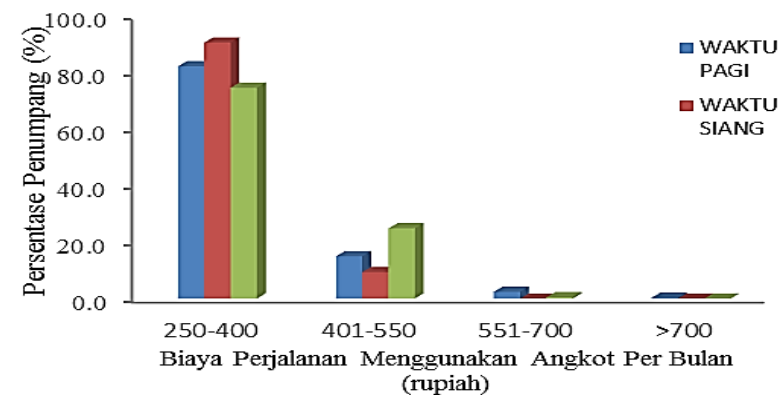

Gambar 9. Grafik berdasarkan biaya perjalanan

\section{Persepsi Penumpang}

a. Menghindari Kemacetan

Dari hasil persepsi responden dapat dilihat bahwa bagaimana angkutan kota dapat menghindari kemacetan. Kemampuan menghindari kemacetan angkutan umum kota (mikrolet) trayek SudiangSentral masih dikategorikan rendah yaitu pada pagi hari dengan tingkat persentase yaitu sebanyak $65.2 \%$ dari jumlah penumpang, pada siang hari dengan tingkat persentase yaitu sebanyak $53.1 \%$ dari jumlah penumpang dan pada sore hari yaitu sebanyak $67.3 \%$ dari jumlah penumpang. Persepsi penumpang terhadap kemampuan angkutan kota.

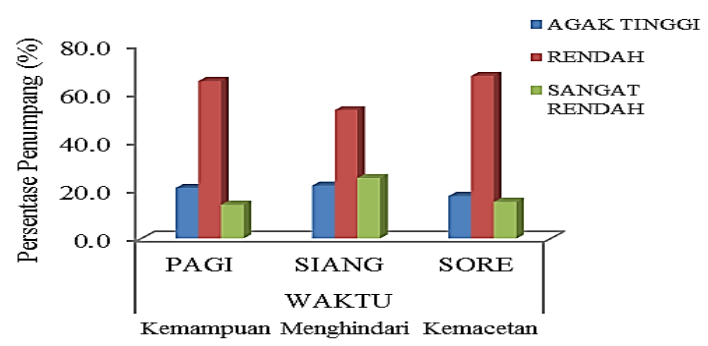

Gambar 10. Persepsi penumpang terhadap kemampuan angkutan kota menghindari kemacetan

\section{b. Ketepatan Waktu}

Dari hasil pengamatan dapat dilihat bahwa ketepatan waktu pada angkutan kota (mikrolet) trayek SudiangSentral masih dikategorikan lama dengan tingkat persentase pada pagi hari yaitu sebanyak $72.1 \%$ dari jumlah penumpang, pada siang hari dengan tingkat persentase sebanyak $84.4 \%$ dari jumlah penumpang dan pada sore hari dengan tingkat persentase sebanyak $79.0 \%$ dari jumlah penumpang. Persepsi penumpang terhadap ketepatan waktu angkutan umum dapat dilihat pada Gambar 11 .
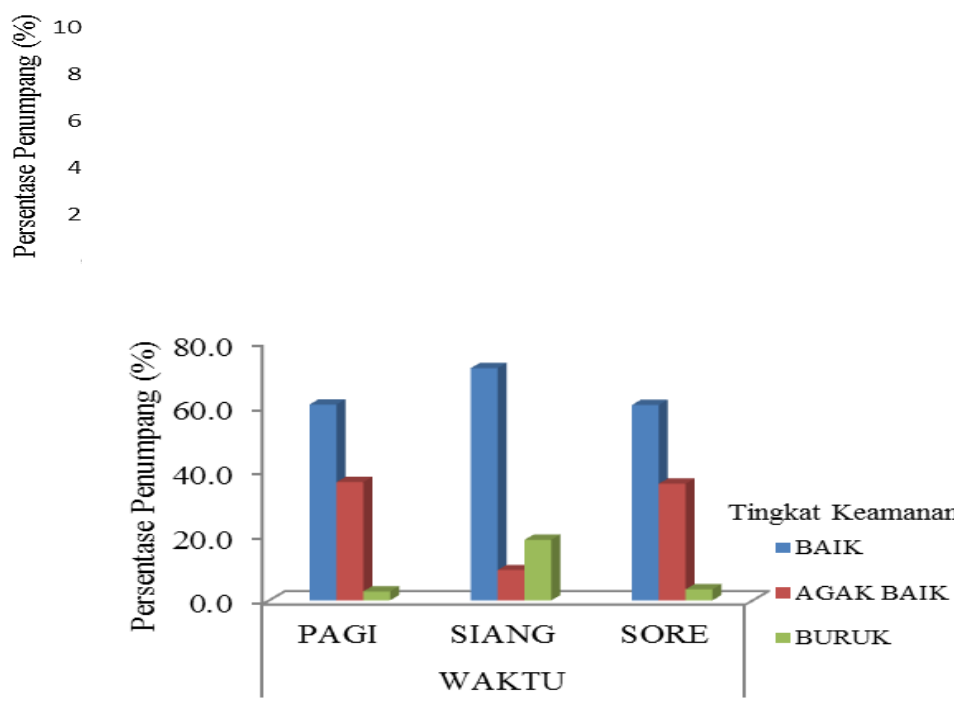

Gambar 11. Persepsi penumpang terhadap
ketepatan waktu

c. Daya Jelajah

Dari hasil penelitian dapat dilihat bahwa daya jelajah angkutan umum (mikrolet) pada trayek SudiangSentral pada pagi hari agak tinggi yaitu sebanyak $28.6 \%$ dari jumlah penumpang, untuk siang hari yaitu sebanyak $21.9 \%$ dari jumlah penumpang, untuk sore hari yaitu sebanyak $26.3 \%$ dari jumlah penumpang sedangkan pada daya jelajah yang rendah terjadi pada pagi hari yaitu sebanyak $71.4 \%$ dari jumlah penumpang, untuk siang hari yatu sebesar $78.1 \%$ dari jumlah penumpang dan untuk sore hari yaitu sebanyak $73.7 \%$ dari jumlah penumpang. Persepsi penumpang terhadap daya jelajah angkutan umum disajikan pada Gambar 12. 


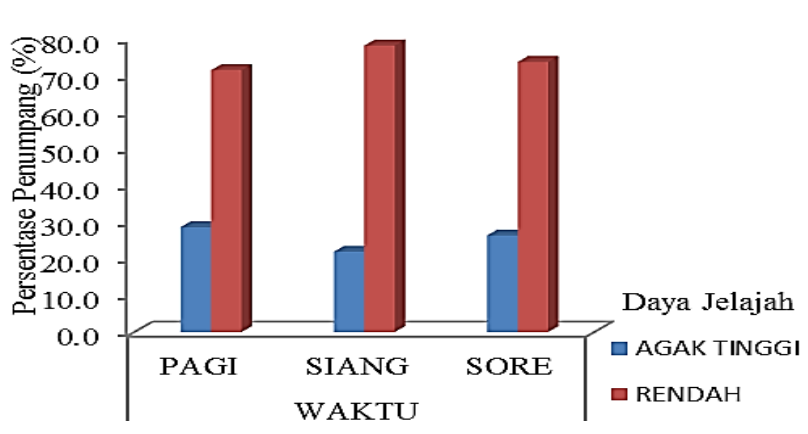

Gambar 12. Persepsi penumpang terhadap kemampuan daya jelajah angkutan kota

\section{d. Tingkat Keamanan}

Dari hasil penelitian dapat dilihat bahwa tingkat keamanan pada trayek Sudiang-Sentral terlihat pada kategori baik untuk pagi hari yaitu sebanyak $60,6 \%$ dari jumlah penumpang, untuk siang hari yaitu sebanyak $71.9 \%$ dari jumlah penumpang, untuk sore hari yaitu sebanyak $60.5 \%$ dari jumlah penumpang. Responden yang mengatakan bahwa tingkat keamanan pada kategori agak baik di pagi hari yaitu sebanyak $36.6 \%$ dari jumlah penumpang, untuk siang hari yaitu sebanyak $9.4 \%$ dari jumlah penumpang dan pada sore hari yaitu sebanyak $36.1 \%$ dari jumlah penumpang sedangkan tingkat keamanan pada kategori buruk untuk pagi hari yaitu sebanyak $2,8 \%$ dari jumlah penumpang, untuk siang hari yaitu sebanyak $18.8 \%$ dari jumlah penumpang dan pada sore hari yaitu sebanyak $3.4 \%$ dari jumlah penumpang.

\section{e. Tingkat Kenyamanan}

Dari hasil penelitian dapat dilihat tingkat kenyamanan pada angkutan kota (mikrolet) pada pagi hari untuk kategori baik yaitu sebanyak $68.6 \%$ dari jumlah penumpang, untuk siang hari yaitu sebanyak $78.1 \%$ dari jumlah penumpang, untuk sore hari yaitu sebanyak $74.1 \%$ dari jumlah penumpang. Tingkat kenyamanan pada kategori agak baik pada pagi hari yaitu sebanyak $31.4 \%$ dari jumlah penumpang, untuk siang hari yaitu sebanyak $21.9 \%$ dan pada sore hari yaitu sebanyak $25.9 \%$ dari jumlah penumpang. Persepsi penumpang terhadap kenyamanan di angkutan kota dapat dilihat pada Gambar 13.

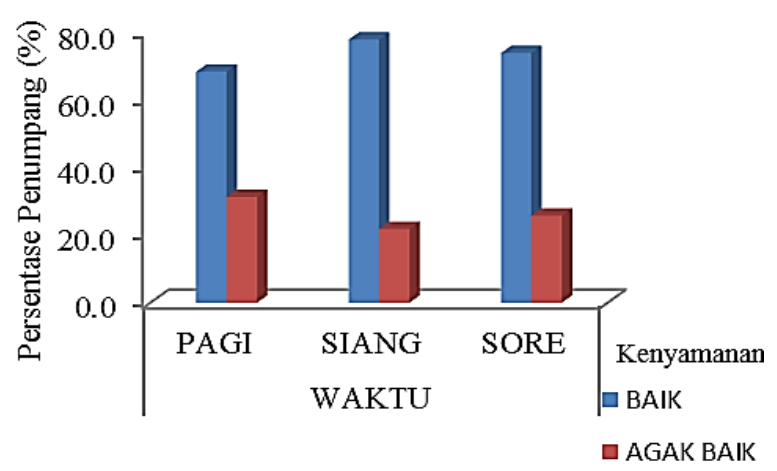

Gambar 13. Persepsi penumpang terhadap tingkat kenyamanan di angkutan kota

\section{f. Penumpang pada Pagi Hari}

Pada pagi hari pengguna angkutan umum kota (mikrolet) pada trayek Sudiang-Sentral paling banyak digunakan oleh perempuan dengan tingkat persentase sebanyak $86.4 \%$ dari jumlah penumpang, dimana yang menaiki angkutan umum tersebut berumur antara 20-29 tahun dengan tingkat persentase sebanyak $50.9 \%$ dari jumlah penumpang dan Jenis pekerjaan yang paling banyak yaitu pekerja swasta dengan persentase sebanyak $27.5 \%$ dari jumlah penumpang dengan tingkat pendidikan terakhir yaitu S1 sebanyak $40.8 \%$ dari jumlah penumpang tersebut.

Berdasarkan penghasilan per bulan pengguna jasa angkutan umum kota (mikrolet) pada trayek SudiangSentral yaitu berpenghasilan sebesar Rp $3.000 .000,00$ - Rp 4.000.000,00 per bulannya dengan presentase $37.6 \%$ dari jumlah penumpang, dimana jarak tempuh yang dilalui penumpang yaitu paling banyak pada jarak 10-14 km dengan presentase $39.7 \%$ dari jumlah penumpang. Waktu tempuh normal didominasi pada waktu tempuh 21-30 menit dengan persentase sebesar $32,4 \%$ dari jumlah penumpang dengan rantai perjalanan yaitu dari rumah ke kantor dengan presentase yaitu sebesar $73.2 \%$ dari jumlah penumpang dan biaya perjalanan sebesar Rp 250.000-Rp 400.000 per bulannya dengan tingkat persentase sebesar $82.2 \%$ dari jumlah penumpang. Berdasarkan persepsi penumpang ketepatan waktu yang dilalui masih terbilang lama dengan tingkat persentase sebesar $72.1 \%$ dari jumlah penumpang dan kemampuan menghindari kemacetan serta daya jelajah masih dalam kategori rendah dimana tingkat persentase untuk menghindari kemacetan yaitu sebesar $65.2 \%$ dan tingkat persentase untuk daya jelajah sebesar $71.4 \%$ dari jumlah penumpang. Namun tingkat keamanan dan kenyamanan dapat dikategorikan baik sesuai dengan persepsi penumpang dimana tingkat persentasenya $60.6 \%$ dan $68.6 \%$ dari jumlah penumpang.

\section{g. Penumpang pada Siang Hari}


Pada siang hari pengguna angkutan umum kota (mikrolet) pada trayek Sudiang-Sentral paling banyak digunakan oleh perempuan dengan presentase sebanyak $87 \%$ dari jumlah penumpang dimana yang menggunakan angkutan umum tersebut berumur antara 20-29 tahun dengan persentase sebanyak $43.8 \%$ dari jumlah penumpang dan Jenis pekerjaan yang paling dominan yaitu pekerjaan lainya (Ibu Rumah Tangga) dengan persentase sebanyak 34.4\% dari jumlah penumpang dengan tingkat pendidikan terakhir yaitu pendidikan lainnya (TK,SD,SMP) sebanyak $43.8 \%$ dari jumlah penumpang tersebut.

Berdasarkan penghasilan per bulan pengguna jasa angkutan umum kota (mikrolet) pada trayek SudiangSentral yaitu tidak berpenghasilan dengan tingkat persentase $53.1 \%$ dari jumlah penumpang dimana jarak tempuh yang dilalui penumpang paling banyak pada jarak 5-9 km dan 10-14 km dengan presentase $37.5 \%$ dari jmlah penumpang. Waktu tempuh normal didominasi pada waktu tempuh 10-20 menit dengan persentase sebesar $31.3 \%$ dengan rantai perjalanan yang dilalui yaitu dari rumah ke kantor dengan presentase yaitu sebesar $71.9 \%$ dari jumlah penumpang dimana biaya perjalanannya sebesar $\mathrm{Rp}$ 250.000-Rp 400.000 per bulannya dengan tingkat persentase sebesar $90,6 \%$ dari jumlah penumpang. Berdasarkan persepsi penumpang ketepatan waktu yang dilalui masih terbilang lama dengan tingkat persentase sebesar $84,4 \%$ dari jumlah penumpang dan kemampuan menghindari kemacetan serta daya jelajah masih dalam kategori rendah dimana tingkat persentase untuk menghindari kemacetan yaitu sebesar $53.1 \%$ dari jumlah penumpang dan tingkat persentase untuk daya jelajah sebesar $78.1 \%$ dari jumlah penumpang. Namun berdasarkan persepsi penumpang mengenai tingkat keamanan dan kenyamanan dikategorikan baik dengan masingmasing persentase yaitu sebesar $71.9 \%$ dan $60.5 \%$ dari jumlah penumpang.

\section{h. Penumpang pada Sore Hari}

Pada sore hari pengguna angkutan umum kota (mikrolet) pada trayek Sudiang-Sentral paling banyak digunakan oleh perempuan dengan presentase sebanyak $75.6 \%$ dari jumlah penumpang, dimana yang menaiki angkutan umum tersebut berumur antara 20-29 tahun dengan persentase sebanyak $59.5 \%$ dari jumlah penumpang dan Jenis pekerjaan yang paling banyak yaitu pekerja wiraswasta dengan persentase sebanyak $37.1 \%$ dari jumlah penumpang dengan tingkat pendidikan terakhir yaitu SLTA dengan persentase sebanyak $43.9 \%$ dari jumlah penumpang.

Berdasarkan penghasilan per bulan pengguna jasa angkutan umum kota (mikrolet) pada trayek SudiangSentral yaitu tidak berpenghasilan dengan tingkat persentase $35.1 \%$ dari jumlah penumpang, dimana jarak tempuh yang dilalui penumpang yaitu paling banyak pada jarak 10-14 km dengan presentase $42,9 \%$ dari jumlah penumpang. Waktu tempuh normal yang didominasi pada waktu tempuh 21-30 menit dengan persentase sebesar $37.6 \%$ dari jumlah penumpang dengan rantai perjalanan yang dilalui yaitu dari rumah ke kantor dengan presentase yaitu sebesar $33.2 \%$ dari jumlah penumpang dan biaya perjalanan sebesar Rp 250.000-Rp 400.000 per bulannya dengan tingkat persentase sebesar $74.6 \%$ dari jumlah penumpang. Berdasarkan persepsi penumpang ketepatan waktu yang dilalui masih terbilang lama dengan tingkat persentase sebesar $79 \%$ dari jumlah penumpang dan kemampuan menghindari kemacetan serta daya jelajah masih dalam kategori rendah dimana tingkat persentase untuk menghindari kemacetan yaitu sebesar $67.3 \%$ dan tingkat persentase untuk daya jelajah sebesar $73.7 \%$. Namun berdasarkan persepsi penumpang mengenai tingkat keamanan dan kenyamanan dikategorikan baik dengan masing-masing tingkat persentase yaitu sebesar $60.5 \%$ dan $74.1 \%$ dari jumlah penumpang.

\section{KESIMPULAN}

Berdasarkan karakteristik penumpang yang menggunakan angkutan umum kota (mikrolet) pada trayek Sudiang - Sentral Makassar jenis kelamin didominasi oleh perempuan dengan presentase yang paling banyak pada siang hari yaitu sebesar $87.5 \%$ dari jumlah penumpang. Umur didominasi rentang umur 20-29 tahun. Pekerjaan didominasi para pekerja wiraswasta dengan presentase yang paling banyak pada sore hari yaitu sebesar $37.7 \%$ dari jumlah penumpang. Tingkat pendidikan terakhir didominasi oleh SLTA sebanyak $43.9 \%$ dari jumlah penumpang, penghasilan per bulan dengan tingkat presentase terbesar yaitu sebanyak $53.1 \%$ dari jumlah penumpang dengan jenis penghasilan tidak tetap/tidak berpenghasilan, moda yang digunakan paling banyak angkutan kota, jarak tempuh yang dilalui didominasi pada jarak 10-14 km dengan presentase $42.9 \%$ dari jumlah penumpang. Waktu tempuh normal didominasi pada waktu tempuh 21-30 menit sebesar $37.6 \%$ dari jumlah penumpang. Rantai perjalanan yang dilalui pengguna jasa angkutan umum kota (mikrolet) lebih banyak dari rumah kekantor dengan presentase 59.44\% dari jumlah penumpang, biaya perjalanan para pengguna jasa angkutan umum didominasi pada biaya $\mathrm{Rp} 250.000$ Rp 400.000 per bulannya.

Berdasarkan persepsi penumpang mengenai kinerja angkutan umum kota (mikrolet) pada trayek Sudiang - Sentral Makassar, kemampuan menghindari kemacetan : Sebanyak 67.3\% dari jumlah penumpang mengatakan masih dalam kategori rendah, kategori kecepatan waktu : sebanyak $84.4 \%$ dari jumlah penumpang mengatakan masih dalam kategori lama, untuk daya jelajah : sebanyak 
$78.1 \%$ dari jumlah penumpang mengatakan masih dalam kategori rendah, tingkat keamanan : Sebesar $71.9 \%$ dari jumlah penumpang mengatakan sudah baik, dan tingkat kenyamanan : sebesar $78.1 \%$ dari jumlah penumpang mengatakan sudah baik.

\section{DAFTAR PUSTAKA}

[1] "Merencanakan Sistem Perangkutan / Suwardjoko Warpani." [Online]. Available: http://library.um.ac.id/freecontents/index.php/buku/detail/merencanakansistem-perangkutan-suwardjoko-warpani17028.html.
[3] H. Cipta, "Pelayanan Transportasi Umum Bus Damri Khusus Wanita di Kota Surabaya," p. 19.

[4] N. Damayanti, "Analisis Kualitas Pelayanan Jasa Penumpang Angkutan Laut di Unit Pelaksana Teknis Pos Lintas Batas Laut Liem Hie Djung Kabupaten Nunukan," p. 167.

[5] S. Haryono, "Analisis Kualitas Pelayanan Angkutaan Umum di Kota Yogyakarta," vol. 7, p. 14, 2010.

[6] M. Aprilyani, "Analisis Kepuasan atas Kualitas Pelayanan Angkutan Umum Bus Damri di Kota Bandung (Studi pada Trayek Leuwipanjang Dipatiukur Non AC)," p. 8.

[7] M. S. Buamona, "Analisis Pelayanan Transportasi Angkutan Kota di Kota Ternate," p. 14. 